Віват Ганна,

доктор філологічних наук, професор, завідувач кафедри українознавства та лінгводидактики

Одеська національна академія харчових технологій

\title{
АНАТОЛІЙ ВАСИЛЬОВИЧ КОЗЛОВ (мої спогади про спілкування 3 професором)
}

Перше моє знайомство 3 професором Козловим Анатолієм Васильовичем відбулося в Кривому Розі 2003 року на Всеукраїнській науково-теоретичній конференції: «Українська література: духовність і ментальність», організатором котрої він був. По приїзді до місця призначення нас, втомлених нелегкою дорогою, привітною усмішкою підбадьорив середнього зросту приємний чоловік і запросив до зали. Це й був господар заходу, заради якого ми сюди приїхали. Конференція була цікавою. Багато відомих науковців там було, а тому засідання рясніли різноманітними глибокими думками, несподіваними пропозиціями. Деякі виступи вражали своєю креативністю. Загальне враження від зустрічі $з$ тими людьми були неоднозначними і надовго закарбувалися в пам'яті. Проте найбільше все ж мені запам'ятався привітний, усміхнений, гостинний господар, розважливий і мудрий науковець хороший організатор, він уміло керував усім тим дійством і спрямовував його у потрібне русло. Таким він мені сподобався, таким і зараз його уявляю, можливо тому, що найперше враження про людину міцно закарбовується в пам'яті.

Друга моя зустріч із професором Козловим А. В. відбулася вже безпосередньо на захисті дисертації в Кіровограді 23 січня 2005 року. Анатолій Васильович, як член ради, в якій я захищала кандидатську дисертацію, вочевидь нею зацікавився. Безпосередньо під час процедури захисту він взяв до рук екземпляр моєї дисертації, довго уважно ії перелистував, щось навіть нотував у своєму записничку. Мені здалося, що так прискіпливо мій скромний науковий здобуток ще ніхто не вивчав, а тому було дуже цікаво і дещо лячно дізнатися його вердикт. Тим приємніше було почути схвальні слова на свою адресу від такого високоповажного професора. 
Пізніше ми часто зустрічалися на наукових конференціях як у Кривому Розі, де господарем був Анатолій Васильович, так і в інших містах, де ми були гостями. Мені завжди було приємно спілкуватися 3 цим розважливим, спокійним і статечним чоловіком. Напевне, це не була дружба у прямому іiі розумінні, але приязнь і повага між нами була. Почути його думку про якусь проблему, пораду про шляхи розв'язання якогось питання та й просто послухати виступ досвідченого вченого на тему літератури, культури, філософії тощо для мене було завжди важливо. Шкода, що так мало було тих зустрічей, виступів, бесід, полемік, розмов. Тільки втративши, починаємо глибше розуміти ціну тієї втрати. Шкода, шкода, шкода...

Одеса, вересень 2018 року 